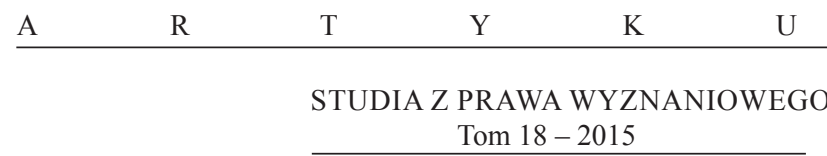

KONSTANTINOS PAPASTATHIS*

\title{
CHURCH JURISDICTIONAL FRAGMENTATION, RELIGIOUS DISCOURSE AND PUBLIC POLICY: THE GREEK CASE
}

\section{INTRODUCTION}

This paper explores the Church's jurisdictional fragmentation as a factor for the formation of public policy in respect to religious issues. The case study looks at Greece and the established Orthodox Church, which is divided into five different church organizations. Contrary to conventional wisdom, this division has an adverse effect on the political operation; the hypothesis explored in this paper is whether the State has exploited this peculiarity in church structure in order to promote certain policies that could potentially face opposition from one of the ecclesiastical institutions. The paper argues that the State, following the 'divide and rule' doctrine via the exploitation of the endemic difference between church organizations, might have found a helping hand to counteract certain reactions coming from the religious bureaucracy in Athens. To this end, the paper contextually investigates the identity card question that arose at the beginning of the century, and critically examines the relevant discourse of senior church officials. The method of analysis builds on the so-called Essex School paradigm of discourse analysis ${ }^{1}$.

* PhD, Research Unit: Identités. Politiques, Sociétés, Espaces (IPSE), Faculty of Language and Literature, Arts and Education, University of Luxembourg, Campus Belval, Maison des Sciences Humaines 11, Porte des Sciences, L-4366 Esch-sur-Alzette, e-mail: konstantinos.papastathis@uni.lu. 
This paper is divided into 5 sections. After the present introductory part, the second section sketches out the diverse administrative status of each ecclesiastical jurisdiction and the effects of the bi-polar division of the church's operation. The third section elaborates on the state-church relationship both from an institutional and a socio-political perspective. The fourth section examines analytically the role of the Ecumenical Patriarchate in the identity card crisis, paying special emphasis on the political causes and effects of its intervention. Finally, the fifth concluding section evaluates the costs and benefits for each party involved in the affair. Overall, the paper suggests that through the instrumental use of the antagonism between the Church institutions, it might be feasible for the Greek government to establish political norms and proceed to take legal measures of secular character in a country of intense religiosity, while managing to mitigate the possible electoral losses.

\section{THE CHURCH JURISDICTIONS}

Instead of having a centralized ecclesiastical administration, the Greek territory is divided into five distinct ecclesiastical jurisdictions, each having a different power structure and regulatory framework. They are:

a) The Autocephalous Church of Greece (ACG), which comprises the Dioceses of Central Greece, Peloponnesus, the Cyclades islands, the Ionian Islands and Thessaly.

b) The so-called Church of the 'New Lands', which consists of the Dioceses of Macedonia, Epirus and Thrace. Together with the

${ }^{1}$ The Essex School paradigm is the qualitative examination of discourse as a network of meaning, articulating both linguistic and non-linguistic elements, in which a 'privileged signifier' (such as 'nation', 'people', 'religion', etc.), functions as the 'nodal point', the centre, of the discursive structure and thus determines its core meaning. For more details on the methodology, see: Ernesto Laclau and Chantal Mouffe, Hegemony and Socialist Strategy, (London: Verso, 1985), 112-113; David Howarth and Yannis Stavrakakis, "Introducing Discourse Theory and Political Analysis," in Discourse Theory And Political Analysis, edited by Dawid R. Howarth, Aletta J. Norval and Yannis Stavrakakis (Manchester: Manchester University Press, 2000), 10-13; Marianne Jorgensen and Louise J. Phillips, Discourse Analysis as Theory and Method (London: SAGE, 2002), 24-59. 
ACG, it forms the administrative jurisdiction of the Orthodox Church of Greece (OCG). However, the Dioceses of the 'New Lands' are still dependent spiritually from the authority of the Patriarch of Constantinople, who also enjoys a number of prerogatives over them.

c) The Church of the Dodecanese Islands, which is completely under the jurisdiction of Constantinople.

d) The semi-autonomous Church of Crete, which is under the supervision of the Patriarchate of Constantinople.

e) The monastic community of Mount Athos, which is administratively self-governed by the Holy Council of the Monasteries' representatives; Mount Athos depends spiritually on the Patriarchate ${ }^{2}$.

This fragmentation has led to the formation of two antagonistic power poles: a) the Church of Greece; and b) the Patriarchate of Constantinople. Various disputes have occurred between them, the onset of which dates back to the nineteenth century, and are grounded on ideological and political foundations. On the one hand, the ideological discourse of the Patriarchate has been articulated on the basis of 'Orthodox Ecumenism', i.e. the criterion for belonging to the collective body is faith per se. As such, it has an internationalist and 'inclusionist' character. On the other hand, nationalism has formed the 'nodal point', i.e. the central ideological feature, of the OCG's historical narrative. Defining the 'us' vs. 'them' distinction along ethnic lines has produced the 'invented tradition' of Helleno-Orthodoxia, according to which the Orthodox religious belonging is related by definition to the Greek national identity: Greek means Orthodox and vice versa ${ }^{3}$. In effect,

${ }^{2}$ For more details on the diverse ecclesiastical structures see: Ioannis Konidaris, A handbook of Ecclesiastical Law (Athens-Thessaloniki: Sakkoulas Publications, 2011), 79-90 and 267-283 (in Greek); Constantinos G. Papageorgiou, Ecclesiastical law: theory \& jurisprudence (Thessaloniki: Barbounakis Publications, 2013), 47-90, 589-591, 645-649, and 677-693 (in Greek); Charalampos Papastathis, Ecclesiastical law (Athens-Thessaloniki: Sakkoulas Publications, 2007), 53-77 (in Greek).

${ }^{3}$ Pantelis Lekkas, The nationalist ideology: Five case studies in historical sociology (Athens: Katarti, 1996), 178-194 (in Greek); Paschalis Kitromilidis, "'Imagined Communities' and the origins of the national question in the Balkans," in National Identity and Modern Greece, edited by Thanos Veremis (Athens: MIET, 1997), 116-117 (in Greek); Orthodox 
Helleno-Orthodoxia as the dominant ideological frame has historically attributed to the OCG as an 'exclusionist' and 'ethno-phyletic' quality.

From a political perspective, the concealed antagonism between the two Churches is grounded on the idea that the official Church of an independent country, like the OCG, cannot be under the rule of an institution, which in turn is under the control of a state that is viewed as the historical 'enemy' of the Greek nation, i.e. Turkey. The Schism between the two institutions (1833-1852) $)^{4}$, the question of the Diaspora jurisdiction (1918-1924), or lately the question on the 'New-Lands' jurisdiction $^{5}$, have been issues in which this dichotomy became apparent within the polemical discourse of the Greek clerical establishment. Overall, the relationship between the two Church institutions has always been characterized by a mutual sense of suspiciousness, which in some cases developed into an open controversy. Depending on the circumstances, the Greek political system has at times fuelled the rivalry and at other times prevented its escalation in order to serve domestic or diplomatic ends. This paper suggests that, eventually, the Greek political elites may view Constantinople and its more liberal ideological frame of reference as a potential instrument for counteracting the rigorist reactions generated by the religious bureaucracy in Athens against the implementation of a secular agenda. The question that arises then is why the Church's standpoint is so paramount for the Greek Government that renders indispensable for the latter to search for alliances, in order to apply a modernist public policy. To the end of a plausible explanation, the next section sketches out the hegemonic role played by the OCG in Greek party politics, both from an institutional and a structural perspective.

Christianity in 21st Century Greece: the Role of Religion in Politics, Ethnicity and Culture, edited by Victor Roudometof and Vasilios N. Makrides (Farnham: Ashgate, 2010).

${ }^{4}$ Charles Frazee, The Orthodox Church and Independent Greece, 1821-1852 (Cambridge: Cambridge University Press, 1969); Paraskevas Matalas, Nation and Orthodoxy: The Vicissitudes of a Relationship: from the 'Greek' to the Bulgarian Schism (Heraklion: Crete University Press, 2002).

${ }^{5}$ Constantinos Vavouskos, The Legal-Canonical Status of the Dioceses of the New Lands (Thessaloniki: Patriarchal Institute for Patristic Studies, 1973) (in Greek); Demetrios Kommatas (Metropolitan of Sebasteia), The Patriarchal and Synodal Act of 1928 (Thessaloniki: Photomethexis, 2006) (in Greek). 


\section{CHURCH AND STATE RELATIONS}

Greece may be considered as one of the most de-secularized states in Europe. The dominant position of religion within Greek society has both institutional (legal), as well as structural (social and political) foundations. From an institutional point of view, Greece has been defined as a 'fully regulated' religious market, ${ }^{6}$ where a form of 'state-law rule system' is applied and the Orthodox Church enjoys preferential treatment because: a) it is recognized as the 'prevailing' religion of the state, i.e. the official religion; b) together with the old-established Jewish and Muslim communities, the Orthodox institutions are legal persons under public law, while the other denominations after decades of non-legal recognition have recently acquired the status of 'religious personality' under private law $^{7}$, and c) the Orthodox Church has enjoyed various privileges, as well as a powerful status within the state apparatus ${ }^{8}$. From a structural perspective, the OCG's prevailing status should be perceived as pathdependent, being linked to the country's mono-confessional composition, to the lack of a 'pluralized' religious landscape, as well as to the social norms pertaining in the Orthodox commonwealth at large. Moreover, the Reformation and the Enlightenment cleavages, which formed the catalyst for the development of the modern social structures, exerted relatively little influence to the East. The maintenance of the traditional

${ }^{6}$ Mark Chaves and David Cann, "Regulation, Pluralism, and Religious Market Structure: Explaining Religion's Vitality,” Rationality and Society 4, no. 3(1992): 272-290.

${ }^{7}$ See Law 4301/2014 Organization of the legal form of religious communities and their associations in Greece and other provisions of the General Secretariat of Religious Affairs competence and other provisions Accessed December, 10, 2015, http://www.hellenicparliament.gr/en/Nomothetiko-Ergo/Anazitisi-Nomothetikou-Ergou?law_id=cf2170b4-3091-4f2 6-b2ce-170a93d744c4

${ }^{8}$ Nicos Alivizatos, “A New Role for the Greek Church?," Journal of Modern Greek Studies 17(1999): 23-40; Yannis Konidaris, Handbook of Ecclesiastical Law, (AthensThessaloniki:, Sakkoulas, 2011) (in Greek); Konstantinos Papageorgiou, Ecclesiastical Law. Theory and Jurisprudence: State and Church Relations, Religious Freedom, Administration and Organisation of Religions, (Thessaloniki: Barbounakis, 2013) (in Greek); Charalambos Papastathis, "State and Church in Greece", in State and Church in the European Union, edited by Gerhard Robbers (Baden-Baden: Nomos Verlag, 2005): 115-38; Charalamos Papastathis, "Il finanziamento statale della religione dominante in Grecia," Quaderni di Diritto e Politica Ecclesiastica XIV: 1(2006): 51-66. 
norms produced subsequently important counter effects for the development of the Greek political value-system. Notably, the most important effect of this development was that religion represented, for the collective conscience, the cohesive element par excellence of the Greek 'imagined' national group 9 . it worked in parallel as the means for the construction of the 'other', both in relation to the West and the Muslim East, picturing both as the 'foreign enemies'. By naming itself, as well as through the construction of negative stereotypes for the 'others', religion generated a narration for the collective past, in which its image was sketched as the protector of the primordial myths of Greek nationalism. As such, the OCG's prevailing status has been represented as an integral part of the traditional 'order of things' and, thus, unquestionable.

The dominant status of the Church in Greek society is clearly reflected in the high rates of religiosity. Overall, the data on the variables for the religious belonging, church attendance, and frequency of prayer indicate an advanced state of religious commitment, establishing Greece as one of the most religious countries in Europe ${ }^{10}$. The high religiosity rate in Greece has produced a twofold political effect:

a) The Church, due to its significant social capital, probably forms the most powerful interest group within Greek politics. It lobbies to seek rents from the political establishment so as to reproduce its authority, and to influence the decision-making process, as well in order to serve its various ends ${ }^{11}$. In exchange for the preferential treatment,

\footnotetext{
${ }^{9}$ See note 3 .
}

${ }^{10}$ The following statistical evidence, derived from the EVS 1981-2008 Longitudinal Data File, is characteristic: a) $84.3 \%$ is self-identified as a religious person; b) $18 \%$ attend church service at least once a week, while the number of churchgoers 'once a month' is high as well $(21.2 \%)$; c) $40.8 \%$ pray to God every day, $13.1 \%$ more than once a week and $7.7 \%$ once a week (the more or less frequent prayers comprise about $60 \%$ of the total). It is interesting to note also that: a) $38.5 \%$ believe that the non-faithful politicians should not take up public offices. The number of those who take a neutral stance on this question is high as well $(20.9 \%)$; and b) $22 \%$ think it would be better if more people with strong religious beliefs were in public office. The number of those who take a neutral stance on this question is high as well $(37.5 \%)$.

${ }^{11}$ On the representation of the Church as an interest group see: Carolyn M. Warner, Confessions of an Interest Group: the Catholic Church and Political Parties in Europe (Princeton: Princeton University Press, 2000). 
the Church has constituted, historically, a pillar for the shaping of social consent. To put it cynically, it is an actual 'trade off'.

b) Despite the fact that religious cues have a certain importance in guiding voting behavior ${ }^{12}$, the maintenance of the Church's preferential treatment enjoys broad public agreement, regardless of the position of the governing party within the political spectrum. In short, the Church's privileges are more or less safe since religion is part of the ideological position of the median voter, the so-called 'zone of acquiescence', since the various catch-all parties articulate their discourse and implement their policies on the basis of this particular voter's perceptions in order to gain popular support ${ }^{13}$.

The question that then arises is what happens when the Government is compelled to legislate on policy issues related to the religious agenda against the will of the Orthodox Church of Greece, due to an EU statute (e.g. art. 10 of the Lisbon Treaty) or to an ECHR ruling. Which are the possible instruments at the Government's disposal in order to implement such measures without losing its religious constituency? The paper argues that a means for counteracting the reactions of the powerful Church of Greece is to involve in the discussion the

${ }^{12}$ On the so-called 'modernization cleavage', namely that the voter's electoral preference is explained along the religious/secular divide and particularly that there is a link between high religiosity and Right voting, see: Religion and Mass Electoral Behaviour in Europe, ed. David Broughton and Hans-Martien ten Napel (London: Routledge, 2000); Wouter van Der Brug, Sara B. Hobolt and Claes H. De Vreese, "Religion and Party Choice in Europe," West European Politics 32, no. 6(2009): 1266-1283; Michael Minkenberg, "Party Politics, Religion and Elections in Western Democracies," Comparative European Politics 8, no. 4(2010): 385-414. As regards particularly the question whether the religiosity factor is a relatively strong predictor for structuring partisan alignment in Greece or not, see: Vassiliki Georgiadou and Elias Nikolakopoulos, "Dimensions of Religious Commitment, Ecclesiastical Practices and Political Preferences: an Empirical Analysis", in Religions and Politics in Modernity, edited by Th. Lipovats, N. Demertzis and V. Georgiadou (Athens: Kritiki, 2002): 254-279 (in Greek); Konstantinos Papastathis, "Religious Discourse and Radical Right Politics in Contemporary Greece, 2010-2014", Politics, Religion and Ideology, (formerly) Totalitarian Movements and Political Religions), 16: 2/3 (2015): 218-247.

${ }^{13}$ Pippa Norris and Joni Lovenduski, "Why Parties Fail to Learn: Electoral Defeat, Selective Perception and British Party Politics," Party Politics 10, no. 1(2004): 83-102. 
Ecumenical Patriarchate of Constantinople, whose spiritual jurisdiction and symbolic authority is paramount. An indicative case to this point has been the so-called 'identity card-question'.

THE 'IDENTITY CARD' CRISIS:

THE INTERVENTION OF CONSTANTINOPLE

The election of Bishop Christodoulos as Archbishop (1998) signified a 'fundamentalist' turning point in the contemporary history of the Greek Church. The ideological vacuum, the de-politicization of the public agenda and the consistent and positive media coverage contributed to the representation of Christodoulos as a political messiah; he was seen as an authentic delegate of the people's will whose authority should be above the law. Within this context, Christodoulos was described as the ultimate judge of the political authorities, while the social body was identified with the Orthodox Church at large ${ }^{14}$. The clash with the centre-left government was only a matter of time. The governmental decision to erase religious affiliation from the identity card's data, a measure backed by all legal bodies and associations as well as the EU, triggered the latent controversy. Christodoulos demanded on behalf of the Church, that if not the abolition of the measure, that it should be at least optional. In short, each citizen would have the right to choose whether his/her religious affiliation would be inscribed on his/her identity card. To this end, he proceeded the coordination of an unofficial referendum. Part of his campaign was to organize two rallies, one in Athens and one in Thessaloniki, which had massive participation. While backed by the conservative political parties, Christodoulos also gathered about three million signatures, almost one third of the Greek population ${ }^{15}$.

${ }^{14}$ Yannis Stavrakakis, "Religious Populism and Political Culture: the Greek Case," South European Society and Politics 7, no. 2(2002): 29-52; Yannis Stavrakakis, "Politics and Religion: on the "Politicization" of Greek Church Discourse," Journal of Modern Greek Studies 21, no. 2(2003): 153-181; Yannis Stavrakakis, "Antinomies of Formalism: Laclau's Theory of Populism and the Lessons from Religious Populism in Greece," Journal of Political Ideologies 9, no. 3(2004): 253-267.

${ }^{15}$ On the 'Identity Card' question, see: Antonis Manitakis, The Relation of the Church to the Nation-State, in the Shadow of the Identity Cards Issue (Athens: Nepheli, 2000) (in 
The government was, on the other hand, in desperate need to find allies to counterweight Christodoulos' symbolic authority. It may be said that one of the most influential persons was the Patriarch of Constantinople. Overall, Patriarch Bartholomew theoretically kept a neutral stance, but practically supported the government. His intervention in the affair took place at the time when Christodoulos' campaign was at its height, directly favoring the government's position. Their opposition produced a paradox effect: in contrast to the secular character of Christodoulos' rhetoric, Bartholomew articulated his discourse essentially on principal axioms of religious tradition. On the one hand, Christodoulos attempted to impose a new framework of operation for Greek politics; this new 'quasi-rigorist' framework employed a politicized discourse, articulating on the 'nodal point' of the modernist ideological features of populism $^{16}$. On the other hand, Bartholomew defended the secularization principle of church-state separation, while structuring his discourse on the basis of Orthodox theology and Canon Law.

In particular, according to the Patriarch, the Church should not be rebellious against the decisions of State authorities, where the validity ought to be respected regardless of the content of the legislation enacted; its members should obey the Governmental ruling and be lawful ${ }^{17}$. Moreover, Bartholomew communicated his annoyance towards Christodoulos for not consulting him on this affair, as he ought to according to Orthodox Canon Law ${ }^{18}$. In conjunction to that, Bartholomew pointed out that the Church is not allowed to reduce its spiritual work in order to focus on affairs 'of secondary importance'. He also made clear that the patriarchate had excellent relations with the Greek Government and had

Greek); Lina Molokotos-Liederman, "Identity Crisis: Greece, Orthodoxy, and the European Union," Journal of Contemporary Religion 18(2003): 291-315; Elizabeth Prodromou, "Negotiating Pluralism and Specifying Modernity in Greece: Reading Church-State Relations in the Christodoulos Period," Social Compass 51, no. 4(2004): 471-485.

${ }^{16}$ Stavrakakis, Politics and Religion, op. cit.; Nicos Chrysoloras, "The Political Discourse of the Greek Orthodox Church," Journal of the Hellenic Diaspora 30, no. 1(2004): 97-119.

${ }^{17}$ The Orthodox Church should not disobey the Law (28/5/2000) [http://archive.in.gr/ news/reviews/article.asp? IngReviewID=842517\&lngItemID=288972] (in Greek).

${ }^{18}$ Phanar is discontent with the Church of Greece on account of the identity card issue (20/6/2000) [http://archive.in.gr/news/reviews/article.asp?lngReviewID=842517\&lngItemI $\mathrm{D}=282767$ ] (in Greek). 
fruitful cooperation ${ }^{19}$. In his letter to the Greek prime-minister, Bartholomew praised his prudence and made clear his respect for the State's exclusive prerogative to define the content of public documents, such as the identity cards ${ }^{20}$.

Bartholomew's support for the Government was not limited only at the theoretical and media level, by de-constructing the religious validity of Christodoulos' claims, but it also had an important practical aspect. This was the absolute prohibition of the Greek Church to collect signatures for its unofficial referendum in the territories under patriarchal jurisdiction within or outside Greece (such as Crete or the Dodecanese Islands, as well as in the Greek Diaspora communities) ${ }^{21}$. In the opposite case, a canonical offence would be committed with major consequences for the perpetrator. Not to mention that without the activation of the local clerical apparatus, any effort on Christodoulos' part could not have any chance of success. Taking into account the number of Greek Orthodox populations within these regions, it is evident that the Greek Church lost access to a large pool of potential supporters.

In conjunction to the above, Bartholomew organized a 10-day visit in Athens, during which he met the prime minister and other state officials, thus de-stigmatizing their authority at a time when the OCG represented the government as an instrument of global conspiracy organized by the enemies of the nation against its alleged spiritual substance. The reaction of Christodoulos was erratic. He implied that the Patriarch served the purpose of governmental propaganda ${ }^{22}$, while the Synod officially asked for the suspension of Bartholomew's visit to Athens. Moreover, Greek clergymen close to Christodoulos described the Patriarchate's position as a 'stab in the back of the archbishop', or

${ }^{19}$ New sideswipes of Bartholomew against the Church of Greece on the identity card issue (12/6/2000) [http://archive.in.gr/news/reviews/article.asp?lngReviewID=842517\&lng ItemID=284926] (in Greek).

${ }^{20}$ Letter of the Ecumenical Patriarch to the Prime Minister on the identity card issue (13/6/2000) [http://archive.in.gr/news/reviews/article.asp?lngReviewID=830577\&lngItemI $\mathrm{D}=284337$ ] (in Greek).

${ }^{21}$ Manolis Vasilakis, The Curse of God (Athens: Gnoseis, 2006): 372 (in Greek).

${ }^{22}$ Vasilakis, The Curse of God, 459. 
as the behaviour of an evil stepmother and not of the mother-church ${ }^{23}$. In response to these allegations, Bartholomew characterized 'parricidal' all those who did not respect the status of the patriarchal institution $^{24}$, and rejected the claim to cancel his visit in Athens as a 'rude' and 'unacceptable' act ${ }^{25}$. Before the threat of opening a second front, Christodoulos had no other option but to cave in and concede to his canonically superior will. During his stay, Bartholomew pointed out that the Church should neither divide nor cultivate prejudice ${ }^{26}$, a statement that targeted the nationalist and exclusionist rhetoric of Christodoulos, and condemned any attempt of the Church to adopt a secular frame of operation and discourse ${ }^{27}$. Moreover, he made crystal clear that if the Greek Church attempted to change unilaterally its status, he would pose canonical sanctions against its officials ${ }^{28}$. The Greek Government in return represented the Patriarch as the authentic voice of Orthodoxy, in contrast to the arrogance and intemperance of the Greek $\operatorname{archbishop}^{29}$. These allegations were stated before Bartholomew, who did not even attempt to give an excuse for his brethren; in contrast, he

${ }^{23}$ Vasilakis, The Curse of God, 442; To overcome the divisions that challenge the Greeks (31/8/2000) [http://news.in.gr/greece/article/?aid=262063] (in Greek); Banqueters, Simitis and Christodoulos, "Rizospastis" (24/10/2000) [http://www.rizospastis.gr/story. do? id=500465] (in Greek).

${ }^{24}$ Patriarchate - Church of Greece: quarrelling for the... incense, "Rizospastis" (18/4/2001) [http://www.rizospastis.gr/story.do?id=751746] (in Greek).

${ }^{25}$ Grigoris Kalokairinos, Blows from within against Mr. Christodoulos, "Kathimerini" (26/9/2001) [http://www.kathimerini.gr/101235/article/epikairothta/ellada/voles-ek-twnesw-kata-toy-k-xristodoyloy] (in Greek).

${ }^{26}$ The effects of secularization divert Orthodoxy from its aims (23/10/2000) [http://news. in.gr/greece/article/?aid=239971] (in Greek).

${ }^{27}$ Extreme reaction of Bartholomew against the scenario of turning the Church of Greece into a Patriarchate (24/10/2000) [http://archive.in.gr/news/reviews/article.asp?lng ReviewID=657386\&lngItemID $=239863$ ] (in Greek).

${ }^{28}$ Gregorios Kalokairinos, A head on attack of Christodoulos, "Kathimerini”'(10/10/2001) [http://www.kathimerini.gr/102439/article/epikairothta/politikh/kata-metwpon-epi8esh-xris todoyloy] (in Greek).

${ }^{29}$ Grigoris Kalokairinos, Blows from within against Mr. Christodoulos, "Kathimerini" (26/9/2001) [http://www.kathimerini.gr/101235/article/epikairothta/ellada/voles-ek-twnesw-kata-toy-k-xristodoyloy] (in Greek). 
praised the domestic and foreign policy of the Government ${ }^{30}$, creating, thus, the necessary political space for the legitimization of the Government's communication strategy against Christodoulos.

In conclusion, although officially Bartholomew kept a neutral stance, by asking both sides to reconcile, the fact that he did not side with the Greek Church and acknowledged emphatically the competency of the Government to legislate on the question without the interference of Christodoulos, indicates that the Patriarch actually sided with the Government. Why then did he contribute in reducing the social reactions against state legislation against the will of the main Church Organization in Greece? The reasons for the Patriarchate's pro-governmental stance are related to its overall political strategy and operation: First of all, the Patriarchate is dependent on the Greek government for financial and diplomatic assistance. On the one hand, its economic means have been reduced because of: a) the decline of the Orthodox population in Istanbul; b) the overall secularization process; and c) Turkey's expropriation policy of the Orthodox community property and endowments (waqf) ${ }^{31}$. On the other hand, because of the aggressive attitude of Turkey, reflected in the non-recognition of the patriarchal legal status and religious authority ${ }^{32}$, the Patriarchate has been the protégé of Greece in the diplomatic arena, not only in relation to Ankara, but also to the EU and its institutions as well as to the other international fora.

Besides these general policy factors, the Patriarchate's intervention was linked: a) to its position within the Turkish legal framework; and b)

${ }^{30}$ Meeting between Simitis - Christodoulos - Bartholomew, "Rizospastis" (25/10/2000) [http://www.rizospastis.gr/story.do?id=503063] (in Greek).

${ }^{31}$ Konstantinos Tsitselikis The Greek Orthodox community Waqfs before the European path of Turkey (Athens: Vivliorama, 2011) (in Greek); Dilek Kurban and Konstantinos Tsitselikis, A Tale of Reciprocity: Minority Foundations in Greece and Turkey (Istanbul: TESEV/KEMO, 2010).

${ }^{32}$ Fredrik Sejersted, Comments on the Legal Status of non-Muslim Religious Communities in Turkey and the Rights of the Orthodox Patriarchate of Istanbul to use the Adjective "Ecumenical", European Commission for Democracy through Law (Venice Commission), Opinion no. 535/2009, Strasbourg, 23 February 2010; The Ecumenical Patriarchate, Memorandum: Problems Faced by the Ecumenical Patriarchate, 5 May 2006 [http://www. archons.org/pdf/issues/E.P._Problems_faced.pdf ] 
to the balance of ecclesiastical power within the Orthodox's commonwealth. In particular, the ultra-nationalist discourse of Christodoulos created problems for Constantinople. Being under the repressive Turkish regime, which has largely violated the rights of the Orthodox minority $^{33}$, the Patriarchate of Constantinople could not but oppose Christodoulos. This was because the Greek Archbishop viewed the Human Rights framework as a first order threat for the Church value system, while for the Patriarch it was a tool employed to counteract the Turkish anti-minority legislation, e.g. the banning of the Chalki Theological Seminar. For Christodoulos, Turkey was the primordial and institutional enemy of Greece, as well as an 'outgroup' of Europe; the Christian character of which had to be protected by all possible means from the Turkish and Muslim 'invaders'. For Bartholomew, promoting an anti-nationalist and anti-orientalist agenda on the basis of concepts, such as conciliation and co-existence as well as by working actively for Turkey's entrance in the EU, was a condition sine qua non for counteracting the negative stereotype constructed within the Turkish society against his institution as being allegedly the 'fifth column' of Greece and the West; he thus secured the Patriarchate's proper operation within a pre-dominantly Islamic country. Not to mention that Christodoulos being a rigorist himself, had a quasi-hostile attitude in respect to the relations with the other Churches, perceiving them as a possible corrupting element and a threat to doctrinal purity ${ }^{34}$. On the other hand, strengthening inter-denominational links via ecumenical dialogue has been a primary aim of Bartholomew's agenda, as from a diplomatic perspective it is a safety valve for the Patriarchate's operation. In short, Christodoulos advocated Greek ethno-phyletism and anti-westernism, while Bartholomew advocated for multi-culturalism and the human-

${ }^{33}$ Dilek Güven, Nationalismus und Minderheiten. Die Ausschreitungen gegen die Christen und Juden der Türkei vom September 1955 (München: Oldenbourg Verlag, 2012); Speros Vryonis, The Mechanism of Catastrophe: The Turkish Pogrom of September 6-7, 1955, and the Destruction of the Greek Community of Istanbul (New York: Greekworks, 2005). See also the relevant annual reports on religious freedom prepared by the U.S. Department of State, 'International Religious Freedom Report on Turkey' [http://www.state.gov/j/drl/rls/ $\mathrm{irf} /$.

${ }^{34}$ Vasilakis, The Curse of God, 246-260. 
rights value system; Christodoulos attempted to establish his value framework, against which Bartholomew fought in order to be able to operate freely and without any state coercion.

Figure 1

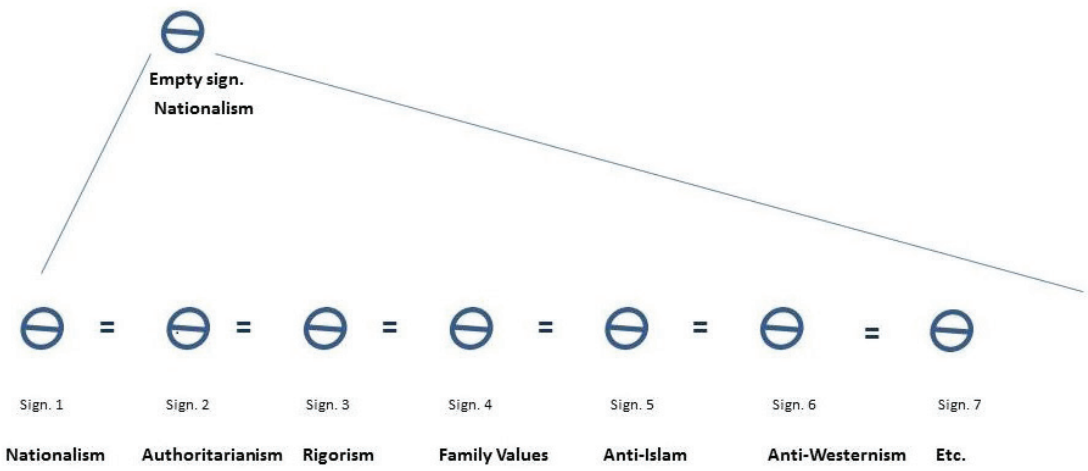

Orthodox Church of Greece

Discursive Chain

Figure 2

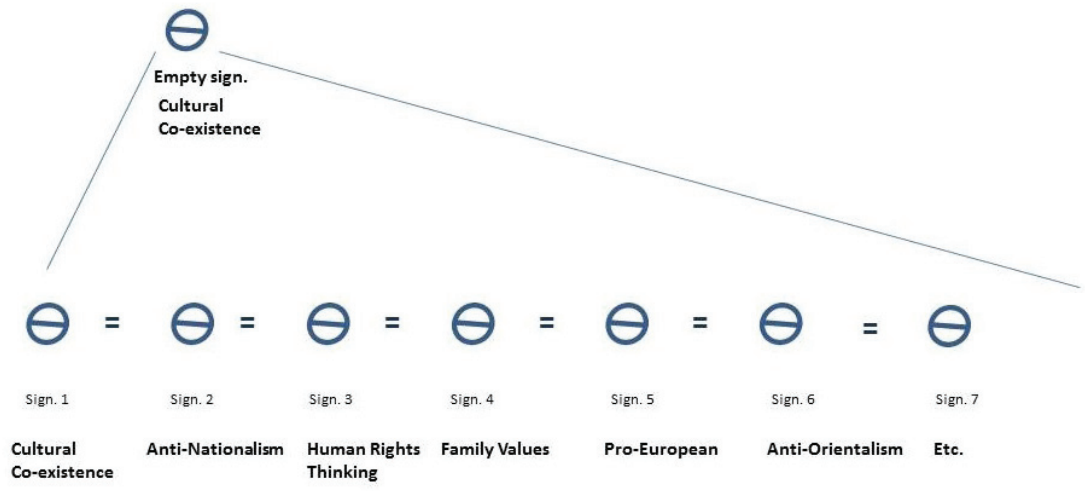

Ecumenical Patriarchate of Constantinople

Discursive Chain

From an ecclesiastical-politics perspective, Christodoulos had the ambition to extend his jurisdiction to the territories under Bartho- 
lomew's direct or indirect supervision. In particular, he was accused of planning the incorporation of the New Lands territories to the complete control of Athens and the promotion of the Church of Greece into a Patriarchate. Moreover, he undermined Bartholomew's authority as the prime Orthodox Church representative in the EU and created links with the Moscow Patriarchate against that of Constantinople, accepting the Russian claims in respect to the Esthonian Orthodox Church ${ }^{35}$. In short, Christodoulos' activation both at the political and religious level questioned not only the power of the Greek Government, but also the authority of the Ecumenical Patriarchate.

The political and ecclesiastical ambitions of Christodoulos rendered the collaboration between the socialist Government and the Ecumenical Patriarchate against the 'common enemy' as indispensable. It was actually a win-win situation. Bartholomew supported the governmental party to overcome without a major political cost from its controversy with Christodoulos. As an exchange, the government authorized the operation of the patriarchal office in Athens, and guaranteed the maintenance of patriarchal power over the dioceses in its jurisdiction within the Greek territory. It should be noted that patriarchal jurisdiction and privileges are guaranteed by art. 3 of the Constitution, which in conjunction to art. 72, gives actually to the Greek State the right to intervene, when a violation of the ecclesiastical status quo is manifested ${ }^{36}$.

${ }^{35}$ Vasiliakis, The Curse of God, 471-472; Maria Antoniadou, The Orthodox Primati Do not Love Each Other, "To Vima" (24/12/2000) (in Greek).

${ }^{36}$ Article 3: 1 . The prevailing religion in Greece is that of the Eastern Orthodox Church of Christ. The Orthodox Church of Greece, acknowledging our Lord Jesus Christ as its head, is inseparably united in doctrine with the Great Church of Christ in Constantinople and with every other Church of Christ of the same doctrine, observing unwaveringly, as they do, the holy apostolic and synodal canons and sacred traditions. It is autocephalous and is administered by the Holy Synod of serving Bishops and the Permanent Holy Synod originating thereof and assembled as specified by the Statutory Charter of the Church in compliance with the provisions of the Patriarchal Tome of June 29, 1850 and the Synodal Act of September 4, 1928. 2. The ecclesiastical regime existing in certain districts of the State shall not be deemed contrary to the provisions of the preceding paragraph.

Article 72: 1. Parliament in full session debates and votes on its Standing Orders, on Bills pertaining to the election of Members of Parliament, on the subjects of articles 3, 13, 27, 28 and 36 paragraph 1, on the exercise and protection of individual rights, on the operation of political parties, on the granting of legislative power according to article 43 paragraph 4 , on 
In effect, from a political perspective the government had to a certain degree, the competency to decide on the legitimacy of Christodoulos' jurisdictional claims.

\section{CONCLUDING REMARKS}

Bartholomew's intervention had certain costs and benefits for each of the parties involved in the affair. The Government succeeded in partially counterbalancing the campaign of Christodoulos. This had a special political significance, because the stake was not that Christodoulos threatened the authority of the government or the Socialist party's cohesion, but the democratic and secular character of the state per se. In this sense, the government proved strong, structuring a profile that it would not retreat from its agenda, setting at the same time the red lines within which the Church institution could operate. Moreover, the political losses were reduced in the sense that the identity card crisis did not influence the voting behaviour of the religious constituency ${ }^{37}$. Bartholomew, in exchange for his support, won the Government's firm acknowledgment of the ecclesiastical status quo and of his jurisdiction, making it difficult for Christodoulos to implement his claims over the territories under patriarchal jurisdiction. Furthermore, Bartholomew grasped the opportunity to cultivate a moderate profile in line with liberal standards, which established him as the trustworthy representative of Orthodoxy within the diplomatic arena and the European Union, in contrast to his nationalist and fundamentalist brethren. On the other hand, his stance might have probably alienated a part of the more rigorist religious body. As far as Christodoulos was concerned, Bartholomew's intervention

\footnotetext{
the liability of Ministers, on the state of siege, on the civil list of the President of the Republic and on the authentic interpretation of the laws according to article 77 and on every other matter referred to Parliament in full session by special provision of the Constitution or on matters for the provision of which a special majority is required.

${ }^{37}$ Pavlos Vasilopoulos and Christoforos Vernardakis, The Rise and Fall of the Greek Conservative Party: Ideological Realignments and Egocentric Economic Voting at the Dawn of the Financial Crisis, "Paper prepared for presentation at the 61st Political Studies Association Annual Conference", London, UK 19-21 April 2011.
} 
had a negative effect, because it weakened his strategy to stigmatise the Government in moral and national terms.

The paper has examined the question whether state modernising reforms are more applicable within social frameworks characterized by the existence of a centralized and dominant national Church or when the state territory is divided into diverse ecclesiastical jurisdictions. The Greek case indicates that within a de-secularized social framework, where religion is a first-order factor in party politics, the liberalization process and the relevant legislative process may prove a difficult endeavor for the government. The identity card crisis proclaimed that a valuable instrument of the political establishment to counteract the potential negative effects of a Church intervention is to employ other competitive institutions of the same creed against the former's claims. This 'divide and rule' doctrine reduced the dynamic of the Orthodox Greek Church's mobilisation, facilitating the political authorities to apply their agenda.

Further research is needed in order to establish a general thesis or a pattern. The developing Church nationalization process within the Orthodox Commonwealth (e.g. the Ukrainian Question) will probably provide in the future many relevant case studies that might work as examples of how the political authorities employ the problematic relations between Orthodox institutions in order to serve their public policy objectives.

\section{REFERENCES}

Alivizatos, Nicos. “A New Role for the Greek Church?” Journal of Modern Greek Studies 17(1999): 23-40.

Chaves, Mark and David Cann. "Regulation, Pluralism, and Religious Market

Structure: Explaining Religion's Vitality." Rationality and Society 4, no. 3(1992): 272-290.

Frazee, Charles. The Orthodox Church and Independent Greece, 1821-1852.

Cambridge: Cambridge University Press, 1969.

Georgiadou, Vassiliki and Elias Nikolakopoulos. "Dimensions of Religious

Commitment, Ecclesiastical Practices and Political Preferences: an Empirical Analysis." In Religions and Politics in Modernity, edited by Thanos 
Lipovats, Nikos Demertzis and Vasiliki Georgiadou. Athens: Kritiki, 2002 (in Greek).

Güven, Dilek. Nationalismus und Minderheiten. Die Ausschreitungen gegen die Christen und Juden der Türkei vom September 1955. München: Oldenbourg Verlag, 2012.

Howarth, David and Yannis Stavrakakis. "Introducing Discourse Theory and Political Analysis." In Discourse Theory And Political Analysis, Manchester, edited by David R. Howarth; Alleta J. Norval and Yannis Stavrakakis. Manchester: University Press, 2000.

Jorgensen, Marianne and Louise J. Phillips. Discourse Analysis as Theory and Method. London: SAGE, 2002.

Kitromilidis, Paschalis. "Imagined Communities' and the origins of the national question in the Balkans." In National Identity and Modern Greece, edited by Thanos Veremis. Athens: MIET, 1997 (in Greek).

Konidaris, Ioannis. A handbook of Ecclesiastical Law. Athens-Thessaloniki: Sakkoulas Publications, 2011.

Laclau, Ernesto and Chantal Mouffe. Hegemony and Socialist Strategy. London: Verso, 1985.

Lekkas, Pantelis. The nationalist ideology: Five case studies in historical sociology, Athens: Katarti, 1996 (in Greek).

Manitakis, Antonis. The Relation of the Church to the Nation-State, in the Shadow of the Identity Cards Issue. Athens: Nepheli, 2000 (in Greek).

Matalas, Paraskevas. Nation and Orthodoxy: The Vicissitudes of a Relationship: from the 'Greek' to the Bulgarian Schism. Heraklion: Crete University Press, 2002.

Minkenberg, Michael. "Party Politics, Religion and Elections in Western Democracies." Comparative European Politics 8, no. 4(2010): 385-414.

Molokotos-Liederman, Lina. "Identity Crisis: Greece, Orthodoxy, and the European Union." Journal of Contemporary Religion 18(2003): 291-315. Nicos Chrysoloras, "The Political Discourse of the Greek Orthodox Church." Journal of the Hellenic Diaspora 30, no. 1(2004): 97-119.

Norris, Pippa and Joni Lovenduski, "Why Parties Fail to Learn: Electoral Defeat, Selective Perception and British Party Politics." Party Politics 10, no. 1(2004): 83-102.

Orthodox Christianity in 21st Century Greece: the Role of Religion in Politics, Ethnicity and Culture, edited by Victor Roudometof and Vasilias N. Makrides. Farnham: Ashgate, 2010. 
Papageorgiou, Konstantinos. Ecclesiastical Law. Theory and Jurisprudence: State and Church Relations, Religious Freedom, Administration and Organisation of Religions. Thessaloniki: Barbounakis, 2013 (in Greek).

Papastathis, Charalambos. Ecclesiastical law, Athens-Thessaloniki: Sakkoulas Publications, 2007 (in Greek).

Papastathis, Charalambos. "State and Church in Greece." In State and Church in the European Union, edited by Gerhard Robbers. Baden-Baden: Nomos Verlag, 2005.

Papastathis, Charalambos. "Il finanziamento statale della religione dominante in Grecia." Quaderni di Diritto e Politica Ecclesiastica XIV: 1(2006): 51-66.

Prodromou, Elizabeth. "Negotiating Pluralism and Specifying Modernity in Greece: Reading Church-State Relations in the Christodoulos Period." Social Compass 51, no. 4(2004): 471-485.

Religion and Mass Electoral Behaviour in Europe. Edited by David Broughton and Hans-Martien ten Napel. London: Routledge, 2000.

Stavrakakis, Yannis. "Religious Populism and Political Culture: the Greek Case." South European Society and Politics 7, no. 2(2002): 29-52.

Stavrakakis, Yannis. "Politics and Religion: on the "Politicization" of Greek Church Discourse." Journal of Modern Greek Studies 21, no. 2(2003): 153-181.

Stavrakakis, Yannis. “Antinomies of Formalism: Laclau's Theory of Populism and the Lessons from Religious Populism in Greece." Journal of Political Ideologies 9, no. 3(2004): 253-267.

van Der Brug, Wouter, Sara B. Hobolt and Claes H. De Vreese, "Religion and Party Choice in Europe." West European Politics 32, no. 6(2009): 1266-1283.

Vasilakis, Manolis. The Curse of God. Athens: Gnoseis, 2006 (in Greek).

Vavouskos, Constantinos. The Legal-Canonical Status of the Dioceses of the New Lands. Thessaloniki: Patriarchal Institute for Patristic Studies, 1973 (in Greek).

Vryonis, Speros, The Mechanism of Catastrophe: The Turkish Pogrom of September 6-7, 1955, and the Destruction of the Greek Community of Istanbul. New York: Greekworks, 2005.

Warner, Carolyn M. Confessions of an Interest Group: the Catholic Church and Political Parties in Europe. Princeton: Princeton University Press, 2000 . 


\section{JURYSDYKCYJNA FRAGMENTACJA KOŚCIOŁA, DYSKURS RELIGIJNY I POLITYKA PUBLICZNA: SPRAWA GRECKA}

\section{Streszczenie}

Celem opracowania jest zbadanie czy państwo greckie wykorzystuje podział jurysdykcyjny Kościoła Prawosławnego w celu promowania swego świeckiego programu. Do wyjaśnienia tej kwestii autor odwołuje się do kryzysu związanego z dyskusją na temat dowodów osobistych. W tym celu krytycznie analizuje stanowisko zajmowane w tej kwestii przez wyższych urzędników kościelnych. W opracowaniu szczególny nacisk położono także na stosunki między Kościołem a państwem, jak również na przyczyny i skutki ich systemowego sojuszu w coraz bardziej świeckim i wielokulturowym społeczeństwie.

\section{Ttumaczenie: Anna Sieradzka-Wawryszczuk}

Słowa kluczowe: Polityka i religia w Grecji, relacje Państwo - Kościół, wolność sumienia i wyznania, dowody osobiste, Kościół prawosławny w Grecji, Patriarchat Konstantynopolitański

Key words: Politics and Religion in Greece, State-Church relations, freedom of conscience and religion, Identity card, Orthodox Church of Greece, Ecumenical Patriarchate of Constantinople 